\title{
PENGARUH ELECTRONIC WORD OF MOUTH TERHADAP KEPUTUSAN WISATAWAN MELAKUKAN AKTIVITAS DIVING PADA BLUE SEASON BALI
}

\author{
Ni Putu Eka Citra Saraswati ${ }^{1}$ I Made Kusuma Negara ${ }^{2}$, Putu Agus Wikanatha Sagita ${ }^{3}$ \\ Email : citrafparunud@gmail.com¹, kusuma.negara@unud.ac.id², aguswika@unud.ac.id ${ }^{3}$ \\ ${ }^{1,2,3}$ Program Studi Industri Perjalanan Wisata, Fakultas Pariwisata, Universitas Udayana
}

\begin{abstract}
In the era of Marketing 4.0, the rapid digitization has created a new face of competition reflected by shifting business practices, as well as consumer behavior from pre-purchase to postpurchase. Aside from companies that are constantly adaptive to technological advancements, consumers are becoming increasingly social and communal, so marketers need to understand new customer paths, and synergize online and offline interactions. This research aims to analyze the influence of electronic word of mouth towards tourist's decision to do diving activities in Blue Season Bali. The technique of determining the sample used purposive sampling through distribution of questionnaires to 100 tourists who have experienced diving and accessed Blue Season Bali information on social media and website. This research applies data collection techniques which include: observation, interviews, questionnaires, literature study, and documentation. Multiple linear regression was used as an analytical technique to measure the influence of variable $\mathrm{X}$ on variable $\mathrm{Y}$ with SPSS software version 18. The research findings show that the intensity variable (X1) partially has no positive and significant effect on decision to do diving activities $(\mathrm{Y})$ with sig. value $0,812>$ alpha 0,05 . Valence of opinion variable (X2) partially has a positive and significant effect with sig. value $0,010<$ alpha 0,05 . Content variable (X3) partially has a positive and significant effect with sig. value $0,000<$ alpha 0,05 . Intensity, valence of opinion, and content simultaneously have a positive and significant effect with sig. value $0,000<$ alpha 0,05 . The multiple linear regression test implies the results of regression equation, $Y=13,580+(-$ $0,046) \mathrm{X} 1+0,617 \mathrm{X} 2+0,351 \mathrm{X} 3+\mathrm{e}$, with coefficient of determination of $33 \%$.
\end{abstract}

\begin{abstract}
Abstrak: Pada era Pemasaran 4.0, pesatnya digitalisasi telah menciptakan wajah baru persaingan yang direfleksikan oleh pergeseran praktik bisnis, serta perilaku konsumen dari pra-pembelian hingga pascapembelian. Disamping perusahaan yang senantiasa adaptif terhadap kemajuan teknologi, konsumen pun menjadi semakin sosial dan komunal sehingga pemasar perlu memahami customer path baru, serta mensinergikan interaksi online dan offline. Penelitian ini bertujuan untuk menganalisis pengaruh electronic word of mouth terhadap keputusan wisatawan melakukan aktivitas diving pada Blue Season Bali. Teknik penentuan sampel menggunakan purposive sampling melalui distribusi kuesioner kepada 100 wisatawan yang berpengalaman diving serta mengakses informasi Blue Season Bali pada media sosial dan website. Penelitian ini menerapkan teknik pengumpulan data yang meliputi: observasi, wawancara, kuesioner, studi kepustakaan, dan dokumentasi. Regresi linier berganda digunakan sebagai teknik analisis untuk mengukur pengaruh variabel $\mathrm{X}$ terhadap variabel $\mathrm{Y}$ dengan software SPSS versi 18. Temuan penelitian menunjukkan bahwa variabel intensitas (X1) secara parsial tidak berpengaruh positif dan signifikan terhadap keputusan melakukan aktivitas diving $(\mathrm{Y})$ dengan nilai sig. 0,812>alpha 0,05 . Variabel valensi opini (X2) secara parsial berpengaruh positif dan signifikan dengan nilai sig. $0,010<a$ alpha 0,05 . Variabel konten (X3) secara parsial berpengaruh positif dan signifikan dengan nilai sig. $0,000<$ alpha 0,05 . Variabel intensitas, valensi opini, dan konten secara simultan berpengaruh positif dan signifikan dengan nilai sig. $0,000<$ alpha 0,05 . Uji regresi linier berganda menyiratkan hasil persamaan regresi, $\mathrm{Y}=13,580+(-0,046) \mathrm{X} 1+0,617 \mathrm{X} 2+0,351 \mathrm{X} 3+\mathrm{e}$, dengan koefisien determinasi senilai $33 \%$.
\end{abstract}

Keywords: electronic word of mouth, decision to do diving activities, marketing 4.0. 


\section{PENDAHULUAN}

Industri pariwisata merupakan salah satu industri yang menjadi lokomotif perekonomian bagi bangsa Indonesia dan terlihat begitu menjanjikan baik di masa sekarang maupun masa mendatang. Namun, harus disadari bahwa pada era konektivitas saat ini yang ditandai dengan tingginya penetrasi internet, serta perubahan cara kerja bisnis dan customer path, membuat persaingan semakin ketat dan menantang pebisnis untuk mengupgrade praktik pemasarannya sebagai respons terhadap perubahan dunia yang didisrupsi oleh kemajuan Teknologi Informasi dan Komunikasi (TIK). Meningkatnya teknologi komunikasi dan informasi seiring meluasnya jangkauan jaringan serta murahnya harga gawai menjadi pendorong meningkatnya pengguna perangkat bergerak (mobile) dan media sosial global (Databoks, 2018).

Di industri pariwisata, pemasar bersaing dengan mengembangkan kreativitas dalam mengemas konten menarik berformat video, foto, artikel, e-books yang relevan dengan produk wisatanya dan diposting melalui berbagai media sosial populer. Pemasar turisme masa kini memanfaatkan TripAdvisor guna memfasilitasi wisatawan untuk memproses pencarian informasi serta pemberian ulasan dan rating terhadap suatu properti. Beraneka ragam financial technology (fintech), pemasaran omnisaluran, dan gamification juga berpartisipasi dalam mendukung ekosistem digital perusahaan. Menurut Kotler, Kartajaya, dan Huan (2017:52), Teknologi digital juga telah mengubah jalur konsumen, dari 4 tahap tradisional (4A - Aware, Attitude, Act, dan Act Again) menjadi 5 tahap (5A - Aware, Appeal, Ask, Act, dan Advocate).

$$
\text { Penelitian Nielsen }
$$

membuktikan, $83 \%$ responden di 60 negara bergantung pada teman dan keluarga sebagai sumber yang paling bisa dipercaya terkait "iklan", dan 66\% memperhatikan pendapat orang lain yang diposting secara online. Hal tersebut menjadi pendorong utama peneliti untuk melakukan penelitian bertemakan pengaruh electronic word of mouth (eWOM) terhadap keputusan wisatawan melakukan aktivitas diving dalam Marketing 4.0. Thurau, et al. (2004), berpendapat bahwa eWOM merupakan pernyataan yang dibuat oleh konsumen aktual, potensial, atau konsumen sebelumnya mengenai produk atau perusahaan dimana informasi ini tersedia bagi orang-orang ataupun institusi melalui media internet. Sedangkan, Marketing 4.0 adalah pendekatan pemasaran yang menggabungkan interaksi online dan offline antara perusahaan dan pelanggan, memadukan gaya dengan substansi dalam membangun merek, dan akhirnya melengkapi konektivitas mesin-ke-mesin dengan sentuhan manusia-ke-manusia untuk memperkuat keterlibatan pelanggan (Kotler, Kartajaya, dan Setiawan, 2019:50). Tujuan akhir dari Marketing 4.0 adalah mendorong pelanggan dari menyadari ke menganjurkan (Kotler, Kartajaya, dan Setiawan, 2019:64). Untuk mencapai tujuan tersebut, ada tiga sumber pengaruh dalam $e W O M$ yang dapat dianalisis, yaitu: intensity, valence of opinion, dan content.

Menurut Parikh, Behnke, Nelson, Vorvoreanu, dan Almanza (dalam Johye dan Jin-young, 2019:1), untuk mengurangi risiko dan ketidakpastian, serta untuk mengamankan pengalaman yang tak terlupakan, wisatawan cenderung mencari dan berbagi informasi secara luas, lebih lanjut menurut Kotler, et al (dalam Johye dan Jin-young, 2019:3), dijelaskan bahwa konektivitas luas bercirikan koneksi antara mereka yang tidak saling mengenal (ikatan lemah), sedangkan konektivitas sempit ditandai oleh koneksi dengan keluarga dan teman dekat (ikatan kuat). Meskipun keintiman lemah, volume tinggi ikatan lemah dapat memiliki dampak besar dengan memberikan jangkauan yang lebih luas dan lebih beragam terkait informasi online, karena $e W O M$ dapat membuat koneksi antara ikatan lemah (Blazevicetal., 2013). Hasil riset dari Adeliasari, Ivana, dan Thio (2014:229), mengungkapkan bahwa variabel intensity, valence of opinion, dan content berpengaruh secara serempak dan signifikan terhadap keputusan pembelian konsumen di restoran dan kafe di Surabaya.

Dalam mengakomodasi perubahan akibat revolusi teknologi dan vokalnya konsumen, kini pemasar dalam industri pariwisata dapat meningkatkan performanya dengan mengidentifikasi peringkat popularitas properti pada TripAdvisor. Berdasarkan Top 15 TripAdvisor Ranked (dari total 276 Penyelenggara Outdoor Activities di Sanur), peringkat ke-14 diduduki oleh Blue Season Bali yang menjadi obyek penelitian ini. Salah satu faktor yang mendasari pertimbangan memilih Blue Season Bali adalah konsistensi perusahaan 
dalam mengantongi ulasan positif dari wisatawan yang direfleksikan dengan capaian Certificate of Excellence pada tahun 2011, dan 2013 - 2019. Ada tiga faktor penting lainnya yang mendukung dasar keputusan pemilihan Blue Season Bali. Faktor pertama, penyajian reviews pada website Blue Season Bali (www.baliocean.com). Dengan banyaknya wisatawan digital, maka menjadikan peran reviews pada website semakin penting sebagai sumber $e W O M$ kredibel yang mengungkit daya tarik, keingintahuan, dan keyakinan. Untuk menyikapi curiosity, wisatawan dapat menjelajahi reviews lebih lanjut dengan sekali klik pada tampilan TripAdvisor dalam website, lalu akan diarahkan ke laman situs ulasan.

Faktor kedua, pemanfaatan media sosial serta pelayanan informasi yang excellent. Pada Instagram, Facebook, Twitter, dan YouTube Blue Season Bali, telah secara aktif dilakukan distribusi konten menarik, informatif, dan interaktif seputar diving world, yang mana hal ini memicu wisatawan untuk memulai $e W O M$ dengan praktis melalui tombol Share. Pelayanan informasi yang excellent menjadi salah satu topik yang berpotensi menghadirkan $e W O M$, contohnya, Blue Season Bali memberikan pelayanan informasi dengan fast response, dimulai dari menu Get In Touch pada website. Selanjutnya, menjawab need and desire wisatawan melalui penyediaan Blog upto-date yang terhubung dengan dunia diving.

Faktor ketiga adalah dalam konteks pengalaman offline yang ditawarkan kepada wisatawan. Blue Season Bali merupakan properti dengan center type terlengkap di Sanur, yang mana menurut PADI (n.d), diklasifikasikan ke dalam 4 tipe: PADI 5-Star Dive Resort; Career Development Center; TecRec Center; dan Freediving Center. Berbicara tentang PADI, lembaga sertifikasi selam ini berhasil memenangi pangsa pasar dengan persentase $55,60 \%$, disusul oleh Scuba Schools International (SSI) dengan angka 10,53\% (Greg, 2018). Dengan demikian, maka menjadi faktor penting untuk mempertimbangkan Blue Season Bali sebagai obyek penelitian mengingat PADI dikenal sebagai asosiasi pelatihan selam terkemuka di dunia dengan market share terluas sehingga membuat persaingan antar perusahaan yang dibawahinya kian kompetitif.

Penelitian berbasis konsep eWOM dan Marketing 4.0 penting bagi industri maupun pemerintah sebagai langkah strategis untuk menumbuhkan tourism advocate melalui analisis 3 elemen eWOM - intensity, valence of opinion, dan content terhadap keputusan wisatawan berdasarkan jalur 5A. Ketiga sumber pengaruh ini diidentifikasi untuk mengetahui variabel manakah yang paling berpengaruh, sehingga dapat membangun saran yang berfokus pada variabel tersebut dengan pendekatan Marketing 4.0 untuk lebih mengarahkan konsumen dari Aware hingga Advocate.

\section{METODE}

Blue Season Bali yang tepatnya berada di Jalan Danau Poso Gang Wanasari 3B, Sanur, Denpasar Selatan, menjadi lokasi penelitian ini. Hal-hal yang mendasari keputusan memilih Blue Season Bali, diantaranya: pangsa pasar didominasi oleh wisatawan digital, Blue Season Bali berhasil memicu munculnya eWOM melalui sajian reviews pada website dan platform lainnya serta raihan 8 Certificate of Excellence; telah mengintegrasikan beragam media sosial dan membawakan pelayanan informasi yang excellent, serta pengalaman offline yang bernilai unggul, dengan demikian terdapat relevansi dengan kriteria sampel yang ditargetkan.

Dalam penelitian ini, variabel yang dianalisis, meliputi: (X1) Variabel intensity yang terdiri dari indikator (X1.1) Frekuensi mengakses informasi dari situs jejaring sosial, (X1.2) Frekuensi interaksi dengan pengguna situs jejaring sosial, (X1.3) Banyaknya ulasan yang ditulis oleh pengguna situs jejaring sosial; (X2) Variabel valence of opinion dengan indikator (X2.1) Komentar positif dari pengguna situs jejaring sosial, (X2.2) Rekomendasi dari pengguna situs jejaring sosial; (X3) Variabel Content yang mencakup indikator (X3.1) Informasi dive sites yang menarik dan bervariasi pada situs jejaring sosial, (X3.2) Informasi program penyelaman yang bervariasi pada situs jejaring sosial (Courses, Dive Safaris, Snorkeling Safaris, GOPRO), (X3.3) Informasi pelayanan staf yang profesional, knowledgeable, helpful, dan friendly pada situs jejaring sosial, (X3.4) Informasi keamanan perlengkapan selama trip (boat, dive gear), (X3.5) Informasi reasonable price pada situs jejaring sosial, (X3.6) Informasi special offers dari Blue Season Bali pada situs jejaring sosial, (X3.7) Informasi 
kemudahan dalam proses pemesanan dan pembayaran pada situs jejaring sosial; (Y) Variabel Keputusan Melakukan Aktivitas Diving yang terdiri atas indikator (Y1.1) Menyadari layanan Blue Season Bali dari orang lain melalui situs jejaring sosial, (Y1.2) Tertarik dengan layanan Blue Season Bali setelah memperoleh informasi dari situs jejaring sosial, lalu mempertimbangkannya, (Y1.3) Menghubungi teman/keluarga untuk meminta saran, (Y1.4) Menghubungi call center untuk meminta informasi lebih rinci, (Y1.5) Mencari lebih banyak ulasan tentang layanan Blue Season Bali pada situs jejaring sosial, (Y1.6) Melakukan online booking melalui websitelemail, (Y1.7) Menggunakan layanan diving Blue Season Bali lagi pada next trip, (Y1.8) Merekomendasikan Blue Season Bali kepada orang lain melalui situs jejaring sosial. Variabel intensity, valence of opinion, dan content bersumber dari Goyette, et al (2010), sedangkan variabel keputusan melakukan aktivitas diving mengacu pada konsep 5A dari Kotler, Kartajaya, dan Setiawan (2017).

Teknik pengumpulan data yang diterapkan, yaitu: observasi terstruktur secara online dan offline, wawancara terbuka dengan pimpinan Blue Season Bali dan wisatawan, distribusi kuesioner dengan skala Likert, studi kepustakaan, dan studi dokumentasi. Sampel yang disasar adalah sejumlah 100 orang wisatawan berdasarkan perhitungan dengan rumus Hair, et al. (2006). Pengambilan sampel dilakukan secara purposive terhadap wisatawan berkriteria: (1) memiliki pengalaman diving bersama Blue Season Bali, (2) mengetahui informasi layanan diving Blue Season Bali dari orang lain melalui media sosial (TripAdvisor, Facebook, Twitter, Instagram, YouTube) dan website. Data dianalisis melalui uji validitas, uji reliabilitas, statistik deskriptif, uji asumsi klasik, dan regresi linier berganda dengan software SPSS versi 18.

\section{HASIL DAN PEMBAHASAN}

\section{Karakteristik Wisatawan yang Melakukan Aktivitas Diving}

Ditinjau dari karakteristik sosiodemografisnya, wisatawan yang melakukan aktivitas diving pada Blue Season Bali didominasi dengan kewarganegaraan Japanese (29\%), jenis kelamin pria (53\%), usia $21-30$ tahun $(52 \%)$, latar belakang pendidikan sarjana $(31 \%)$, serta profesi karyawan swasta dan tenaga ahli (22\%). Berikutnya, jika ditinjau dari karakteristik perjalanannya, wisatawan yang melakukan aktivitas diving didominasi dengan lama tinggal di Bali dari $1-10$ hari (59\%), pemilihan akomodasi hotel $(51 \%)$, perjalanan hanya dengan seorang diri (38\%), pengeluaran diving senilai Rp. 1.200.000 - <2.200.000 $(40 \%)$, pengeluaran harian yang mencapai Rp. 300.000 - <600.000 (32\%), perolehan sumber informasi dari website (53\%), status first timer (94\%), pemilihan layanan Fun Diving (43\%), pemilihan Bali sebagai destinasi wisata utama (88\%), perencanaan matang sebelum memutuskan diving (74\%), pemanfaatan Facebook untuk mengakses informasi (32\%), penggunaan TripAdvisor untuk mengakses komentar dan rekomendasi (37\%), pengaksesan TripAdvisor untuk menelusuri informasi ulasan $(36 \%)$, serta pemilihan konten dalam format favorit yakni foto $(70 \%)$.

\section{Uji Validitas Instrumen}

Untuk mengetahui validitas dari 20 item kuesioner, digunakan metode post-test terhadap 100 data responden yang selanjutnya dianalisis menggunakan teknik Pearson Product Moment Corelation dengan software SPSS versi 18. Item kuesioner dapat dikatakan valid apabila r-hitung > r-tabel. Nilai r-tabel ditentukan melalui perhitungan $=\mathrm{TINV}(0,05 ; 100) / \mathrm{SQRT}(100+(\mathrm{TI}$ $\left.\mathrm{NV}(0,05 ; 100))^{\wedge} 2\right)$ dengan Microsoft Excel versi 2013, sehingga menghasilkan nilai r-tabel sebesar 0,195. Hasil uji validitas menyatakan bahwa item (Y1.3) menghubungi teman/keluarga untuk meminta saran, dinyatakan tidak valid karena nilai r-hitung lebih kecil dari r-tabel, yakni 0,132 < 0,195. Dengan demikian, item Y1.3 direduksi.

\section{Uji Reliabilitas Instrumen}

Uji reliabilitas instrumen dalam penelitian ini dilakukan terhadap 19 item kuesioner yang lolos uji validitas dengan menggunakan software SPSS versi 18. Berdasarkan hasil uji, diinferensikan bahwa 19 item telah mencapai nilai Cronbach's alpha sebesar 0,858 yang berarti item terbukti reliabel karena melampaui nilai Cronbach's alpha minimal, 0,600, sehingga bisa dilanjutkan ke tahap uji asumsi klasik.

\section{Uji Asumsi Klasik}


Hasil uji multikolinearitas membuktikan bahwa variabel intensity, valence of opinion, dan content terbebas dari gejala multikolinearitas karena nilai tolerance lebih besar dari 0,10 dan nilai VIF kurang dari 10,00. Raihan nilai VIF intensity $=2,134<10,00, V I F$ valence of opinion $=1,853<10,00$, VIF content $=1,494<10,00$, serta nilai tolerance intensity $=0,469>0,10$, tolerance valence of opinion $=$ $0,540>0,10$, dan tolerance content $=0,670>$ 0,10 .

Model regresi dinyatakan bebas dari heterokedastisitas jika nilai signifikansinya melampaui angka 0,05. Setelah melalui uji dengan metode Glejser, diketahui nilai Sig. intensity $=0,876>0,05$, Sig. valence of opinion $=0,940>0,05$, dan Sig. content $=0,861>0,05$. Kesimpulannya, model regresi tidak menunjukkan gejala heterokedastisitas.

Berlandaskan pada metode Kolmogorov-Smirnov untuk menguji normalitas data, acuannya adalah, apabila nilai Asymp. Sig (signifikansi) > dari alpha 0.05, maka data berdistribusi normal. Menurut hasil uji, nilai Asymp. Sig $=0,878>$ alpha 0.05 . Dengan demikian, data yang dikumpulkan pada penelitian ini terbukti berdistribusi normal.

\section{Analisis Regresi Linier Berganda}

Dalam melakukan analisis regresi linier berganda, peneliti menggunakan software SPSS versi 18, dan berikut ini merupakan hasil persamaan regresinya yang telah dikonversikan ke dalam bentuk standarized:

$$
\begin{aligned}
\mathrm{Y}= & 13,580+(-0,046) \mathrm{X} 1+0,617 \mathrm{X} 2+ \\
& 0,351 \mathrm{X} 3+\mathrm{e}
\end{aligned}
$$

Keterangan:

$\mathrm{Y}=$ Keputusan melakukan aktivitas diving

$\mathrm{X} 1=$ Koefisien intensity

$\mathrm{X} 2=$ Koefisien valence of opinion

$\mathrm{X} 3=$ Koefisien content

e $\quad=$ Koefisien estimasi (variabel error)

Penjelasan persamaan regresi di atas, antara lain:

a. Konstanta senilai 13,580 berarti apabila koefisien X1, X2, dan X3 adalah 0, maka nilai Y sebesar 13,580.

b. Koefisien X1 memiliki nilai $(-0,046)$ yang menandakan adanya pengaruh berlawanan arah antara variabel X1 dan Y dikarenakan nilainya negatif. Jika nilai koefisien $\mathrm{X} 1$ mengalami peningkatan, maka nilai $\mathrm{Y}$ akan mengalami penurunan. Sedangkan jika nilai koefisien X1 mengalami penurunan, maka nilai $\mathrm{Y}$ akan mengalami peningkatan.

c. Nilai koefisien X2 adalah 0,617. Angka positif ini menunjukkan pengaruh yang searah antara variabel X2 dan Y. Apabila koefisien X2 terjadi peningkatan, maka nilai $\mathrm{Y}$ akan meningkat. Jika terjadi penurunan nilai pada koefisien $\mathrm{X} 2$, maka nilai $\mathrm{Y}$ juga akan menurun.

d. Koefisien X3 mencapai 0,351, mengindikasikan adanya pengaruh searah antara variabel X3 dan Y. Seandainya nilai koefisien X3 mengalami peningkatan, maka nilai $\mathrm{Y}$ akan ikut meningkat. Bila nilai koefisien X3 mengalami penurunan, maka nilai $\mathrm{Y}$ akan menurun.

Uji Pengaruh Electronic Word of Mouth Terhadap Keputusan Melakukan Aktivitas Diving Secara Parsial

Variabel intensity (X1), valence of opinion (X2), dan content (X3) terhadap keputusan melakukan aktivitas diving (Y) yang telah diuji secara parsial menerangkan hasil sebagai berikut:

a. Intensity (X1) terhadap Keputusan Melakukan Aktivitas Diving (Y)

Berdasarkan pada hasil uji parsial, diketahui bahwa nilai signifikansi variabel intensity $(\mathrm{X} 1)>$ alpha $=$ Sig. 0,812 >0,05, yang artinya tidak terdapat pengaruh positif dan signifikan secara parsial antara variabel intensity (X1) dan variabel keputusan melakukan aktivitas diving (Y). Temuan tersebut sejalan dengan hasil dari beberapa penelitian sebelumnya. Jurnal penelitian yang ditulis oleh Komalasari, et al (2019) menyatakan bahwa variabel intensity yang diteliti dengan indikator frekuensi mengakses informasi, frekuensi interaksi antar pengguna, banyaknya ulasan yang ditulis tidak berbanding lurus atau tidak cukup untuk membuat pengguna kolom komentar secara keseluruhan memutuskan pembelian barang virtual pada game online. Berdasarkan penelitian oleh Poernamawati (2018), diperoleh hasil bahwa tidak terdapat pengaruh signifikan positif secara parsial antara variabel intensity terhadap minat kunjungan. Selanjutnya, skripsi oleh Nugraha (2019) memaparkan temuan bahwa intensitas penggunan Instagram Kafe Kopine Eyang secara parsial tidak memiliki pengaruh yang signifikan terhadap keputusan pembelian pada Kafe Kopine Eyang. 
Indikator penelitian yang terjaring dalam variabel intensity, meliputi: level keseringan mengakses informasi, menjalin interaksi dengan pengguna jejaring sosial, dan frekuensi ulasan yang diperoleh. Penelitian ini membuktikan bahwa mayoritas wisatawan sering mengakses informasi seputar layanan Blue Season Bali pada jejaring sosial, namun tidak sertamerta berinteraksi dengan sesama pengguna dan memperoleh banyak ulasan. Wisatawan yang jarang atau tidak berinteraksi dengan users, mengindikasikan adanya faktor lain yang lebih mengontribusikan pengaruh terhadap keputusan melakukan aktivitas diving, seperti valensi opini. Berikutnya, membahas indikator frekuensi ditemukannya ulasan, hasil pengamatan menunjukkan bahwa TripAdvisor merupakan platform Blue Season Bali yang memuat paling banyak ulasan apabila dikomparasikan dengan platform lainnya, dengan demikian membuat wisatawan nonTripAdvisor users merasa kurang menemukan banyak ulasan pada platformnya. Dalam konteks Marketing 4.0 Kotler, et al (2019:26), saat konektivitas memberdayakan pelanggan dengan dengan informasi berlimpah, pelanggan juga menjadi terlalu tergantung pada pendapat orang lain, yang kerap lebih dipentingkan daripada preferensi pribadi.

b. Valence of Opinion (X2) terhadap Keputusan Melakukan Aktivitas Diving (Y)

Hasil uji parsial menunjukkan bahwa nilai signifikansi variabel valence of opinion (X2) $<$ alpha $=$ Sig. 0,010<0,05, yang artinya variabel valence of opinion (X2) berpengaruh positif dan signifikan secara parsial terhadap variabel keputusan melakukan aktivitas diving (Y). Paparan temuan tersebut relevan dengan hasil dari beberapa penelitian terdahulu. Temuan dalam jurnal Komalasari, et al (2019), menyiratkan bahwa variabel valence of opinion yang mencakup komentar positif, dan rekomendasi dari pengguna berbanding lurus atau cukup untuk membuat pengguna kolom komentar secara keseluruhan terbantu dalam hal memproses keputusan pembelian barang virtual pada game online. Hasil dalam jurnal penelitian oleh Poernamawati (2018), menjelaskan bahwa variabel valence of opinion secara parsial berpengaruh positif dan signifikan terhadap minat kunjungan. Temuan selanjutnya berdasarkan pada skripsi oleh Nugraha (2019), didapati hasil bahwa terdapat pengaruh signifikan dari variabel valence of opinion terhadap keputusan pembelian di Kafe Kopine Eyang.

Valence of opinion yang dimaksud dalam riset ini yakni kekuatan pendapat orang lain yang diutarakan dalam bentuk komentar dan rekomendasi tentang pengalaman diving dengan Blue Season Bali melalui situs jejaring sosial. Hasil observasi mengungkapkan bahwa platform Blue Season Bali telah meraih banyak komentar positif dan rekomendasi wisatawan, sebagai contoh, TripAdvisor. Tak hanya TripAdvisor, jejaring sosial lainnya juga telah mengantongi komentar-komentar positif dan rekomendasi, misalnya, pada Instagram Blue Season Bali, sering dijumpai tindakan repost oleh perusahaan terhadap postingan instastory wisatawan yang mengandung komentar positif bertajuk konten tentang dive trips dan aktivitas saat courses berlangsung. Mayoritas wisatawan first timer yang menggunakan layanan diving Blue Season Bali telah menjadi faktor yang mendukung pentingnya valensi opini dari pelanggan berpengalaman. Karakter wisatawan first timer yang cenderung melakukan pertimbangan detail telah menyebabkannya terarahkan dalam hal perencanaan perjalanan diving dengan matang melalui jejaring sosial. Dengan demikian, opini dan rekomendasi dari pelanggan terdahulu bersifat kredibel dan membantu wisatawan dalam membuahkan keputusan diving. Dalam konteks Marketing 4.0 Kotler, et al (2019:14), pelanggan lebih memperhatikan lingkaran sosial saat membuat keputusan. Mereka meminta nasihat dan ulasan, baik secara online maupun offline.

c. Content (X3) terhadap Keputusan Melakukan Aktivitas Diving (Y)

Hasil uji parsial menyiratkan bahwa variabel content (X3) menyumbangkan pengaruh positif dan signifikan terhadap keputusan melakukan aktivitas diving pada Blue Season Bali (Y) dengan nilai signifikansi variabel content $(\mathrm{X} 3)<$ alpha $=$ Sig. $0,000<$ 0,05 . Output tersebut sejalan dengan beberapa temuan penelitian sebelumnya. Hasil penelitian dari Komalasari, et al (2019) membuktikan bahwa indikator informasi variasi produk, informasi kualitas produk, dan informasi harga yang ditawarkan berbanding lurus atau cukup untuk membuat pengguna kolom komentar secara keseluruhan terbantu dalam memutuskan pembelian. Sebuah jurnal oleh Adeliasari, et al (2014), memaparkan bahwa variabel content $(\mathrm{X} 3)$ memiliki pengaruh positif dan signifikan terhadap variabel keputusan 
pembelian (Y). Selanjutnya, skripsi oleh Nugraha (2019) menyajikan hasil bahwa terdapat pengaruh positif dan signifikan antara variabel content dan keputusan pembelian di Kafe Kopine Eyang.

Indikator dari variabel content yang dianalisis dalam riset ini antara lain: (1) informasi dive sites yang menarik, (2) informasi program penyelaman yang bervariasi, (3) informasi pelayanan staf yang profesional, knowledgeable, helpful, dan friendly, (4) informasi keamanan perlengkapan selama trip, (5) informasi reasonable price, (6) informasi special offers, dan (7) informasi kemudahan dalam proses pemesanan dan pembayaran. Menurut observasi peneliti, keandalan Blue Season Bali dalam merancang konten menarik dan informatif telah dinilai baik. Konten-konten yang berhasil membangun attraction tentunya akan membentuk preferensi pribadi netizen atau bahkan menghadirkan $e W O M$ di lingkarannya. Tak hanya dari sudut keunggulan produksi dan distribusi konten, peneliti mengamati pula adanya frekuensi ulasan positif yang tinggi mengenai tujuh indikator dalam variabel content pada TripAdvisor. Namun, konten tentang tiga indikator pertama adalah konten yang paling mendominasi ulasan.

Content merupakan pemicu kesadaran awal yang menumbuhkan daya tarik pelanggan potensial untuk mempertimbangkan Blue Season Bali lebih lanjut. Pelanggan yang notabene pernah atau sering mengakses informasi produk melalui situs jejaring sosial, hal pertama yang dipelajari adalah content atau informasi produk, seperti layanan dan penawaran harga. Langkah tersebut tentu berpeluang melahirkan eWOM di kalangan netizen dan mengembangkan keyakinan calon pelanggan untuk diving apabila kontennya sukses menarik perhatian dan memenuhi need and desire.

Dalam konteks Marketing 4.0 Kotler, et al (2019:65), pengaruh luar sering menjangkau pelanggan terlebih dahulu. Bila merek berhasil memicu percakapan dengan pengaruh luar, hal ini biasanya diikuti oleh pengaruh orang lain. Akhirnya, cara kedua sumber pengaruh ini berinteraksi akan membentuk pengaruh pelanggan sendiri.

\section{Uji Pengaruh Electronic Word of Mouth Terhadap Keputusan Melakukan Aktivitas Diving Secara Simultan}

Setelah melalui uji simultan, output memperlihatkan adanya pengaruh positif dan signifikan antara variabel intensity (X1), valence of opinion (X2), dan content (X3) terhadap keputusan melakukan aktivitas diving (Y) secara simultan dengan perolehan nilai signifikansi $(0,000)<$ alpha $(0,05)$. Hasil uji simultan tersebut sejalur dengan temuan dari beberapa penelitian terdahulu. Penelitian oleh Komalasari (2019) membuktikan bahwa variabel intensity, valence of opinion, dan content secara bersama-sama berpengaruh signifikan terhadap variabel keputusan pembelian barang virtual pada game online. Penelitian oleh Adeliasari, et al (2014) mengungkapkan bahwa variabel intensity, valence of opinion, dan content berpengaruh secara simultan dan signifikan terhadap keputusan pembelian di restoran dan kafe di Surabaya. Penelitian selanjutnya oleh Poernamawati (2018) menuaikan hasil yakni variabel intensity, valence of opinion, dan content berpengaruh terhadap minat kunjungan. Menurut hasil riset dari Nugraha (2019), diperoleh temuan yang mana terdapat pengaruh dari variabel intensity, valence of opinion, dan content pada Instagram terhadap variabel keputusan pembelian pada Kafe Kopine Eyang.

Pada tahap pertama, Aware, mulanya wisatawan melakukan pencarian informasi perihal dive centre di Bali melalui search engine Google. Berbagai pilihan dive centre yang muncul pada deretan awal, salah satunya Blue Season Bali, membentuk kesadaran wisatawan dan mendorongnya untuk mengeksplor lebih jauh dengan mengklik website Blue Season Bali (www.baliocean.com). Pada website, ditampilkan beragam platform (Facebook, Twitter, Instagram, YouTube, TripAdvisor, $e$ mail) yang mana hal ini menyediakan kesempatan bagi netizen untuk mendalami informasi dengan sekali klik pada pilihan platform. Temuan tersebut relevan dengan mayoritas wisatawan yang memperoleh sumber informasi Blue Season Bali dari website.

Tahap kedua yaitu Appeal dimana wisatawan tertarik pada layanan Blue Season Bali setelah memperoleh informasi dari situs jejaring sosial, lalu mempertimbangkannya. Menurut pendapat Greta yang merupakan salah satu responden, Greta menyukai konten-konten yang diluncurkan oleh Blue Season Bali, khususnya bagi anak muda yang tengah mempertimbangkan program GOPRO. Hal 
tersebut didukung oleh temuan observasi peneliti yang menilai bahwa penyajian konten oleh Blue Season Bali dan pelanggan sebelumnya telah variatif, informatif, dan menarik yang didominasi oleh konten tentang dive sites, pilihan program diving, serta pelayanan staf yang excellent. Sebanyak 70\% wisatawan menyukai konten berformat foto sebab mekanisme akses yang lebih simple dan efisien waktu daripada format blog dan video.

Tahap ketiga, Ask, mencakup aksi menghubungi call center untuk meminta informasi lebih rinci, dan mencari lebih banyak ulasan tentang layanan Blue Season Bali pada situs jejaring sosial. Sebagian wisatawan tidak bertindak menghubungi call center Blue Season Bali dan tidak mencari lebih banyak ulasan, dikarenakan informatifnya konten pada platform dan hadirnya opini positif ternyata telah mengakomodasi kebutuhan informasi dan menumbuhkan keyakinan wisatawan untuk menggunakan layanan diving. Menurut opini seorang responden bernama Suanne, pemasaran digital oleh Blue Season Bali sangat informatif dan profesional. Lebih lanjut menurut Advian, diungkapkan bahwa Advian memilih layanan diving karena ulasan yang bagus dan kemudian mengunjungi kantor Blue Season Bali untuk meminta informasi lebih lanjut.

Tahap keempat adalah Act yang meliputi online booking melalui website atau $e$ mail Blue Season Bali. Setelah dibekali banyak informasi ketika berada di tahap-tahap sebelumnya, inilah titik dimana wisatawan mengembangkan komitmennya. Online booking turut menumbuhkan komitmen untuk melakukan pembelian akibat kemudahan yang ditawarkan. Pada menu Get in Touch dalam website, wisatawan cukup menginput nama, alamat e-mail, subject, serta pesan, dan diakhiri dengan mengklik tombol Send. Tak perlu menunggu lama, Blue Season Bali mengirimkan e-mail konfirmasi tentang kepemilikan lisensi menyelam, penentuan tanggal trip, serta informasi lengkap seputar program yang dipilih.

Tahap kelima adalah advocate yang digambarkan sebagai aksi menggunakan layanan diving Blue Season Bali lagi pada next trip, dan merekomendasikan Blue Season Bali kepada orang lain melalui situs jejaring sosial. Berdasarkan observasi, diketahui ada banyak ulasan yang mengarah ke bentuk rekomendasi pada TripAdvisor dengan topik yang bervariasi, seperti: fasilitas yang menjamin kenyamanan, keanekaragaman biota laut pada setiap dive sites, serta pelayanan prima oleh divemaster dan instructor. Dengan demikian dapat dipahami bahwa wisatawan pada era 4.0 ini mencerminkan karakter komunalnya melalui rekomendasi yang didasari pada kepuasan berwisata minat khusus menggunakan layanan Blue Season Bali. Dalam konteks Marketing 4.0 Kotler et al (2019:12), saat membuat keputusan untuk membeli, pelanggan biasanya didorong oleh preferensi individu serta keinginan akan kesesuaian sosial. Seberapa penting masing-masing faktor ini bervariasi dari satu orang ke orang lain dan juga bervariasi dalam industri serta kategori.

\section{Analisis Koefisien Determinasi}

Hasil perhitungan koefisien determinasi variabel intensity (X1), valence of opinion (X2), dan content (X3) terhadap keputusan melakukan aktivitas diving pada Blue Season Bali (Y) menunjukkan bahwa perolehan nilai $R$ square mencapai 0,330 , yang artinya wisatawan memutuskan diving dengan menggunakan layanan Blue Season Bali dipengaruhi oleh variabel intensity (X1), valence of opinion (X2), dan content (X3) senilai $33 \%$, sedangkan sisanya, $67 \%$, dipengaruhi oleh variabel lain yang tidak diteliti. We shall see that the magnitude of the strength of this relationship, $R^{2}$, can also be influenced by the choice of $X$ values and the sample size (Cornell, J. A., and Berger, R. D., 1987:65).

\section{SIMPULAN DAN SARAN Simpulan}

Variabel intensity (X1) yang meliputi indikator frekuensi mengakses informasi, frekuensi interaksi dengan pengguna, dan banyaknya ulasan yang ditulis pada situs jejaring sosial secara parsial tidak berpengaruh positif dan signifikan terhadap keputusan melakukan aktivitas diving (Y). Variabel valence of opinion (X2) yang terdiri atas komentar positif, dan rekomendasi dari pengguna situs jejaring sosial secara parsial berpengaruh positif dan signifikan terhadap keputusan melakukan aktivitas diving (Y). Sedangkan variabel content (X3) yang mencakup indikator informasi dive sites, informasi program penyelaman, informasi pelayanan staf, informasi keamanan perlengkapan diving, informasi reasonable 
price, informasi special offers, informasi kemudahan booking dan payment pada jejaring sosial memiliki pengaruh positif signifikan dan paling dominan terhadap keputusan melakukan aktivitas diving (Y) secara parsial.

Telah dibuktikan bahwa secara simultan, variabel intensity (X1), valence of opinion (X2), dan content (X3) berpengaruh positif dan signifikan terhadap keputusan melakukan aktivitas diving. Uji regresi linier berganda memaparkan hasil persamaan regresi, yaitu $\mathrm{Y}=13,580+(-0,046) \mathrm{X} 1+0,617 \mathrm{X} 2+$ $0,351 \mathrm{X} 3+\mathrm{e}$. Analisis determinasi menyiratkan temuan bahwa variabel bebas mempengaruhi variabel terikat sebesar 33\%, sedangkan sisanya senilai $67 \%$ dipengaruhi oleh variabel lain yang tidak dianalisis dalam penelitian ini.

\section{Saran}

Di bawah ini dipaparkan saran praktis melalui optimalisasi content yang memperhatikan interaksi online dan offline, machine-to-machine dan human-to-human, serta substansi dan gaya untuk membimbing wisatawan dari tahap Aware hingga Advocate:

a. Menyediakan informasi layanan diving dalam bahasa Cina dan Jepang. Berdasarkan observasi, mayoritas divers asal Jepang dan Cina memiliki pemahaman yang kurang akan bahasa Inggris. Diharapkan saran ini dapat membantu menumbuhkan awareness terhadap pelanggan Asia, khususnya Japanese dan Chinese.

b. Memposting informasi secara intensif pada TripAdvisor. Mengingat TripAdvisor merupakan salah satu platform yang mendominasi penggunaan jejaring sosial oleh wisatawan, maka penting untuk menggencarkan postingan konten pada akun Blue Season Bali, karena berdasarkan pengamatan, intensitas informasi yang diposting pada TripAdvisor terbilang jarang.

c. Memposting professional video tentang eksplorasi dive sites beserta explanation of conditions, interaksi antara instructor dan murid saat menjalani dive courses untuk memberikan gambaran nyata mengenai layanan yang diberikan, terutama bagi beginners dan wisatawan yang belum berpengalaman diving.

d. Meluncurkan interview video dengan wisatawan. Bagi visitor yang tengah meriset informasi pada jejaring sosial Blue Season Bali dan di saat yang sama mendapati informasi interview video, maka hal ini berpotensi membuahkan pertimbangan, keyakinan, dan kesadaran baru melalui eWOM yang mereka ciptakan.

e. Meningkatkan engagement pelanggan melalui postingan pada jejaring sosial, contoh: menjaring foto dan video selama dive trips atau courses lalu menguploadnya pada instastory, livestory, dan IGTV dengan meng-tag akun divers.

f. Mengupload video dan foto yang mengarah pada pelayanan informasi yang excellent, seperti tentang mekanisme kemudahan booking.

g. Meningkatkan kualitas layanan melalui penyediaan free wifi di boat untuk menunjang wisatawan yang ingin mengupload aktivitas diving mereka secara real-time.

h. Memfasilitasi jasa fotografer, lalu menawarkan video serta digital photos kepada pelanggan dengan harga yang wajar atau gratis. Diharapkan layanan ini dapat memenuhi kebutuhan divers akan dokumentasi aktivitas menyelam mereka, sehingga akan memperkuat loyalitas akibat fasilitas yang semakin excellent.

i. Melakukan follow up melalui e-mail dengan menyampaikan ucapan terima kasih kepada pelanggan sekaligus menawarkannya untuk menulis ulasan wisata pada TripAdvisor atau Facebook. Hal ini menjadi bahan evaluasi untuk meningkatkan kualitas pelayanan, di samping semakin bertambahnya ulasan.

Saran akademis yang diajukan untuk peneliti selanjutnya meliputi penambahan jumlah sampel, dan mempertimbangkan variabel lain untuk diteliti yang diduga membawakan pengaruh yang signifikan terhadap keputusan pembelian pelanggan. Variabel bebas potensial yang dapat dianalisis dalam penelitian serupa selanjutnya yakni variabel persepsi nilai - emotional value, social value, functional value, dan value of money. 


\section{Kepustakaan}

Adeliasari, Ivana, V., Thio, S. 2014. "Electronic Word-Of-Mouth (eWOM) dan Pengaruhnya terhadap Keputusan Pembelian di Restoran dan Kafe di Surabaya", Jurnal Hospitality dan Manajemen Jasa Vol. II, no. 2, pp. 218230.

Blazevic, V., Hammedi, W., Garnefeld, I., Rust, R.T., Keiningham, T., Andreassen, T. W., Carl, W. 2013. "Beyond traditional word-of-mouth an expanded model of customer-driven influence", Journal of Service Management, Vol. XXIV, no. 3, pp. 294-313.

Cornell, J.A., Berger, R.D. 1987. "Factors that Influence the Value of the Coefficient of Determination in Simple Linear and Nonlinear Regression Models", Article of The American Phytopathological Society, Vol. LXXVII, no. 1, pp. 63-69.

Databoks. (2018, July 23-last update). "4 Miliar Penduduk Bumi Telah Terkoneksi Internet”, available: https://databoks.katadata.co.id/datapubli sh/2018/07/23/4-miliar-penduduk-bumitelah-terkoneksi-internet (accessed: 2019, August 29).

Goyette, et al. 2010. "E-Wom: Word of Mouth Measurement Scale for E-Service Context", Journal of Administrative Sciences, Vol. XXVII, no. 1, pp. 5-23.

Greg. (2018, December 22-last update), “2018 Market Share of Scuba Certification Agencies (PADI, SSI, NAUI)", available:

http://www.divebuddy.com/blog/12618/ 2018-market-share-scuba-certificationagencies-padi-ssi-naui/ (Accessed: 2020, June 16).

Hennig- Thurau, Thorsten, Kevin P. Gwinner, Gianfranco Walsh, and Dwayne D. Gremler. 2004. "Electronic Word-ofMouth via Consumer-Opinion Platforms: What Motivates Consumers to Articulate Themselves on the Internet?", Journal of Interactive Marketing, Vol. XVIII, no. 1, pp. 38-52.

Johye, H., Jin-young, K. 2019. "Food tourists' connectivity through the $5 \mathrm{~A}$ journey and advocacy: comparison between generations $\mathrm{Y}$ and $\mathrm{X}$ ", Asia Pacific Journal of Tourism Research, Vol. XXV, no. 1, pp. 1-12.
Komalasari, Y., Sulastriningsih, D., Marjito. 2019. "Penerapan eWOM untuk Penentuan Keputusan Pembelian Barang Virtual Game Online (Studi Kasus: Wilayah Jawa Barat)", Jurnal Computech dan Bisnis, Vol. XIII, no. 2, pp. 91-99.

Kotler, P., Kartajaya, H., Setiawan, I. 2017. Marketing 4.0: Moving from Traditional to Digital. New Jersey: John Wiley \& Sons, Inc.

Kotler, P., Kartajaya, H., Huan H.D. 2017. Marketing for Competitiveness: Asia yang Mendunia pada Era Konsumen Digital. Yogyakarta: Bentang.

Kotler, P., Kartajaya, H., Setiawan, I. 2019. Marketing 4.0: Bergerak dari Tradisional ke Digital. Jakarta: Gramedia Pustaka Utama.

Nielsen. (2015, September 28-last update). "Global Trust in Advertising", available: http://www.nielsen.com/us/en/insights/r eports/2015/global-trust-in-advertising2015.html (Accessed: 2020, March 8).

Nugraha, Angga. 2019. "Pengaruh e-WOM (Electronic-Word-of-Mouth) terhadap Keputusan Pembelian (Studi pada Instagram Kafe Kopine Eyang)", Skripsi.

PADI. (n.d). "About PADI Dive Centers and Resorts", available: https://www.padi.com/padi-divecenters/business-levels (Accessed: 2020, June 22).

Parikh, A. A., Behnke, C., Nelson, D., Vorvoreanu, M., \& Almanza, B. 2015. "A qualitative assessment of Yelp.Com users' motivations to submit and read restaurant reviews", Journal of Culinary Science \& Technology, Vol. XIII, no. 1, pp. 1-18.

Poernamawati, Diana Eka. 2018. "Analisis Dimensi Electronic Word of Mouth (eWOM) dan Pengaruhnya terhadap Minat Kunjungan pada Obyek Wisata di Malang Raya", Jurnal Administrasi dan Bisnis Vol. XII, no. 2, pp. 127-137. 